\title{
High in vitro and in vivo survival of day 3 mouse embryos vitrified or frozen in a non-toxic solution of glycerol and albumin
}

\author{
W. F. Rall ${ }^{1}$ and M. J. Wood ${ }^{2}$ \\ ${ }^{1}$ Veterinary Resources Program, National Center for Research Resources, National Institutes of Health, \\ Building 14F, Room 101, Bethesda, MD 20892, USA; and ${ }^{2}$ MRC Experimental Embryology and \\ Teratology Unit, St George's Hospital Medical School, Cranmer Terrace, Tooting, \\ London SW17 ORE, UK
}

\begin{abstract}
A vitrification solution consisting of $6.5 \mathrm{~mol}$ glycerol $\mathrm{l}^{-1}$ and $6 \%(\mathrm{w} / \mathrm{v}) \mathrm{BSA}$ in a modified Dulbecco's PBS (designated solution VS3a) was examined for the cryopreservation of 8-12-cell mouse embryos. Solution VS3a vitrified when cooled to $-196^{\circ} \mathrm{C}$ at rates of $10-2500^{\circ} \mathrm{C} \mathrm{min}{ }^{-1}$ and vitrified suspensions did not crystallize when warmed at 200 or $2000^{\circ} \mathrm{C} \mathrm{min}{ }^{-1}$. However, slow cooling at $5^{\circ} \mathrm{C} \mathrm{min}{ }^{-1}$ or slow warming at $20^{\circ} \mathrm{C} \mathrm{min}^{-1}$ resulted in visible crystallization of solution VS3a. Embryos were equilibrated in solution VS3a in three steps at room temperature and placed into a $0.25 \mathrm{ml}$ plastic straw in a way that permitted in-straw dilution with $1 \mathrm{~mol}$ sucrose $1^{-1}$. Embryos equilibrated in solution VS3a and diluted immediately exhibited high rates of development in vitro to blastocysts (>90\%) if the total time of exposure to $100 \%$ solution VS3a did not exceed 5 min. Embryos exhibited high rates of development in vitro $(75-97 \%)$ when equilibrated in $100 \%$ solution VS3a for $1 \mathrm{~min}$ and then cryopreserved using all combinations of three rates of cooling $\left(5200\right.$ or $\left.2500^{\circ} \mathrm{C} \mathrm{min}^{-1}\right)$ and three rates of warming $\left(20200\right.$ or $\left.2000^{\circ} \mathrm{C} \mathrm{min}^{-1}\right)$. Although embryo suspensions visibly crystallized during slow cooling at $5^{\circ} \mathrm{C} \min ^{-1}$, the rate of cooling was not a significant source of variance $(P>0.26)$. However, the rate of warming was found to have a small but significant effect on embryo survival $(P<0.05)$. Vitrified embryos exhibited a high rate of development in vivo after transfer to foster mothers $(63 \%)$. A paired embryo transfer study comparing vitrification in VS3a with conventional slow freezing in $1.5 \mathrm{~mol}$ glycerol $\mathrm{l}^{-1}$ showed no difference in the rate of development in vivo after either cryopreservation method $(P>0.12)$. These results demonstrate that embryos can be vitrified in solution VS3a by a simple procedure that includes the widest range of cooling and warming conditions reported to date.
\end{abstract}

\section{Introduction}

In the two decades since the first successful cryopreservation of mouse embryos (Whittingham et al., 1972; Wilmut, 1972), basic and applied research has resulted in the cryopreservation of embryos of at least 13 other mammalian species (Rall, 1992a). Improvements have been made in nearly all steps of the cryopreservation process, resulting in considerable simplification of the original slow freezing and thawing procedure. These advances include the use of plastic insemination straws as the sample container (Tsunoda and Sugie, 1977), a reduction of the time needed for controlled freezing to the storage temperature (Willadsen, 1977; Whittingham et al., 1979; Wood and Farrant, 1980), cryoprotectant solutions containing sucrose that osmotically dehydrate embryos before cooling (Massip et al., 1984; Takeda et al., 1984; Szèll and Shelton, 1986), transfer of thawed embryos into recipient females without a period of culture in vitro (Renard and Babinet, 1984), the use of

Received 4 January 1994 sucrose to reduce osmotic swelling during dilution of the cryoprotectant (Leibo and Mazur, 1978), and vitrification procedures that prevent the formation of ice in the embryo suspension during cooling and warming (Rall and Fahy, 1985; Scheffen et al., 1986). These and other studies using mammalian embryos have increased our understanding of the basic mechanisms of cryoprotection and cryoinjury (Leibo, 1986; Mazur, 1990; Rall, 1992a).

Vitrification procedures offer two important advantages over conventional slow freezing approaches. First, potential injury associated with the formation of ice is eliminated because no ice forms in vitrified suspensions during the cooling, storage or warming steps. Second, vitrification permits a substantial reduction in the time and equipment required for cryopreservation. However, rapid cooling is not essential for successful vitrification, although in practice most suspensions are vitrified using ultrarapid cooling procedures. Recent studies indicate that when embryos are dehydrated and vitrified in a mixture of $6.5 \mathrm{~mol}$ glycerol $1^{-1}$ and $6 \%(\mathrm{w} / \mathrm{v})$ polyethylene glycol in a Hepes-buffered saline (VS3), high 
survival is obtained using a wide range of cooling rates $\left(15-2500^{\circ} \mathrm{C}^{-1}{ }^{-1}\right)$ and warming rates $\left(10-2000^{\circ} \mathrm{C} \mathrm{min}^{-1}\right)$ (Rall, 1987).

The greatest challenge for successful vitrification is the formulation of a vitrification solution and an effective equilibration procedure to produce the necessary degree of cellular dehydration and avoid significant toxic or osmotic injury (Rall, 1987). Generally, the choice of vitrification solution (composition, concentration) and equilibration conditions (time, temperature) depend on the permeability characteristics of the cells in question. Considerable progress has been made in reducing toxicity since the first vitrification solution (VS1; Rall and Fahy, 1985) was developed, which required low temperatures (about $4^{\circ} \mathrm{C}$ ) during the final dehydration steps of equilibration. Two vitrification solutions permit all equilibration steps to be performed at room temperature. (i) A mixture of $25 \%(\mathrm{v} / \mathrm{v})$ glycerol and $25 \%(\mathrm{v} / \mathrm{v})$ propylene glycol in PBS yields high survival of mouse (Scheffen et al., 1986) and cattle (Massip et al., 1986) embryos after vitrification. (ii) Similarly, a mixture of $40 \%(\mathrm{v} / \mathrm{v})$ ethylene glycol, $18 \%(\mathrm{w} / \mathrm{v})$ Ficoll and $0.3 \mathrm{~mol}$ sucrose $1^{-1}$ in PBS yields high survival of mouse morulae (Kasai et al., 1990) and bovine blastocysts (Tachikawa et al., 1993) after vitrification. In all four of these studies, embryos were recovered from the straw container before the vitrification solution was diluted. Vitrification solutions containing other mixtures of cryoprotectants have been reported (e.g. Shaw et al., 1991; Ishimori et al., 1992; Tada et al., 1993).

The present study examined the survival of 8-12-cell mouse embryos after: (i) equilibration at room temperature in a vitrification solution (VS3a) consisting of $6.5 \mathrm{~mol}$ glycerol $\mathrm{l}^{-1}$ and $6 \%(\mathrm{w} / \mathrm{v})$ BSA in Dulbecco's PBS; (ii) dilution using the one-step procedure (Leibo, 1984) within the straw container in which the embryos were cryopreserved; and (iii) various combinations of a wide range of cooling and warming rates after equilibration in solution VS3a. Finally, we used a paired experimental design to compare the rate of development of embryos in vivo after cryopreservation by vitrification in VS3a with that after conventional slow freezing in $1.5 \mathrm{~mol}$ glycerol $\mathrm{I}^{-1}$ Preliminary reports of these data appeared elsewhere (Rall, 1992b; Wood and Rall, 1992).

\section{Materials and Methods}

\section{Source and collection of embryos}

Outbred, 3-9-week-old ICR mice (Harlan-Sprague Dawley, Indianapolis, IN) were induced to superovulate by an injection i.p. of 5 iu pregnant mares' serum gonadotrophin G4877; Sigma Chemical Co., St Louis, MO) and 5 iu hCG (CG2; Sigma Chemical Co.) given $44-46 \mathrm{~h}$ apart. Females were paired with $\mathrm{C} 57 \mathrm{BL} / 6 \mathrm{~J} \times \mathrm{DBA} / 2 \mathrm{~J} \quad \mathrm{~F}_{1}$ hybrid males immediately after injecting $\mathrm{hCG}$ and examined the next morning for the presence of a copulation plug (day 1 of pregnancy). On the morning of day 3 of pregnancy $(66 \mathrm{~h}$ after hCG injection), embryos were flushed from the excised uteri and oviducts using either a modified Dulbecco's phosphate-buffered medium (PB1; Whittingham, 1974) supplemented with $3 \mathrm{mg}$ BSA (Miles Pentex, Kankakee, IL) $\mathrm{ml}^{-1}$ or a modified Krebs-Ringer medium with Hepes buffer (M2; Fulton and Whittingham, 1978) supplemented with $4 \mathrm{mg}$ BSA $\mathrm{ml}^{-1}$. After collection, 8-12-cell embryos were washed in fresh collection medium, pooled and kept at about $4^{\circ} \mathrm{C}$ until used.

\section{Vitrification solutions}

The glycerol-based vitrification solution (VS3a) was similar to that described previously (VS3; Rall, 1987) with three exceptions: (i) BSA replaced polyethylene glycol; (ii) solution PBI was used as the solution base; and (iii) the solution was adjusted to $\mathrm{pH}$ 7.2. Solution VS3a, therefore, consisted of a mixture of glycerol $\left(6.5 \mathrm{~mol} \mathrm{l} \mathrm{l}^{-1}\right)$ and BSA $(6 \% \mathrm{w} / \mathrm{v})$ in PBS (final concentrations: $136.9 \mathrm{mmol} \mathrm{NaCl} \mathrm{I}{ }^{-1}, 2.68 \mathrm{mmol}$

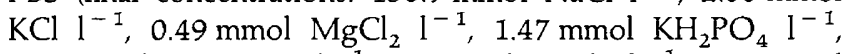
$8.09 \mathrm{mmol} \mathrm{Na}_{2} \mathrm{HPO}_{4} \mathrm{l}^{-1}, 0.9 \mathrm{mmol} \mathrm{CaCl} \mathrm{I}^{-1}, 5.56 \mathrm{mmol}$ glucose $\mathrm{I}^{-1}, 0.33 \mathrm{mmol}$ sodium pyruvate $\mathrm{l}^{-1}, 100$ iu penicillin $\mathrm{G} \mathrm{ml}{ }^{-1}$ and $0.01 \%$ phenol red). Dilutions of solution VS3a were prepared using a solution of PB1 that contained $6 \%(\mathrm{w} / \mathrm{v})$ BSA to yield solutions with $25 \%$ and $65 \%$ of the glycerol

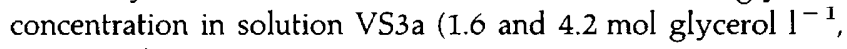
respectively).

\section{Preparation of one-step vitrification straws}

Columns of a diluent solution (1.0 mol sucrose $1^{-1}$ in PB1) and solution VS3a were placed into a plastic insemination straw $(0.25 \mathrm{ml}$, No. A201; IMV, L'Aigle), as shown in Fig. 1. (i) The cotton-polyvinyl alcohol plug was pushed a total of $9 \mathrm{~mm}$ into the straw to facilitate heat sealing. (ii) A column of the diluent solution, $7.5 \mathrm{~cm}$ long, was placed in the straw using a $1 \mathrm{ml}$ syringe fitted with a 27 gauge, $3.8 \mathrm{~cm}$ hypodermic needle. Care was taken to avoid wetting the wall in other sections of the straw when the needle was inserted and withdrawn. (iii) A $1 \mathrm{~cm}$ column of solution VS3a was placed into the straw using a second needle and syringe. The diluent and VS3a solutions were separated by an air bubble gap of $0.5 \mathrm{~cm}$. (iv) The end of the straw closest to the cotton plug was heat-sealed, and a handle $(0.5 \mathrm{ml}$ plastic insemination straw) was slip-fitted over the heat seal.

\section{Exposure of embryos to the vitrification solution}

Groups of between six and 12 embryos at the 8-12-cell stage were washed in PBI containing $6 \%(\mathrm{w} / \mathrm{v}) \mathrm{BSA}$ and then transferred into a solution of $1.6 \mathrm{~mol}$ glycerol $1^{-1}$ and $6 \% \mathrm{BSA}$ in PB1 $\left(25 \%\right.$ VS3a) at room temperature $\left(20-26^{\circ} \mathrm{C}\right)$ for $20 \mathrm{~min}$. Embryos were then rinsed in a solution of $4.2 \mathrm{~mol}_{\text {glycerol }} 1^{-1}$ and $6 \%$ BSA in PB1 (65\% VS3a) and pipetted into the column of solution VS3a in a straw prepared as described above. The total time between placing embryos into $65 \%$ VS3a and pipetting into the straw did not exceed $1.25 \mathrm{~min}$. The straw was then heat-sealed and held horizontally at room temperature before either cooling to $-196^{\circ} \mathrm{C}$ or immediately diluting and recovering the embryos (see below). Care was taken during loading and sealing to prevent warming of the embryo suspension. 


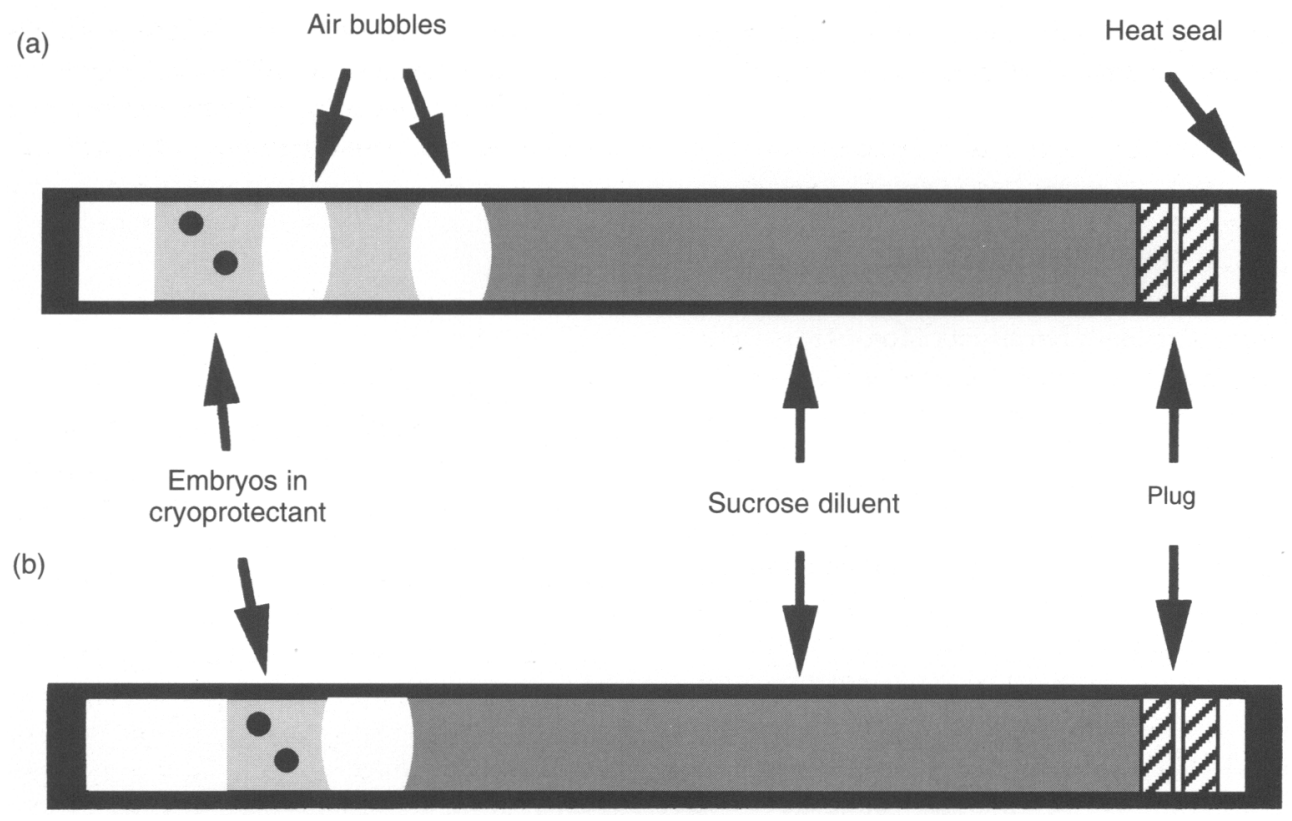

Fig. 1. Diagram of the final configuration of solutions and mouse embryos in $0.25 \mathrm{ml}$ plastic insemination straws for (a) conventional slow freezing in $1.5 \mathrm{~mol}$ glycerol $\mathrm{I}^{-1}$ and (b) vitrification in solution VS3a.

\section{Cooling and warming procedures for vitrified embryos}

After exposure of embryos to solution VS3a for a total of 1 min, straws were cooled using one of three methods. (i) The straws were cooled slowly $\left(5^{\circ} \mathrm{C} \mathrm{min}^{-1}\right)$. Straws were placed in the chamber of a controlled-rate biological freezer (No. R202; Planer, Sunbury-on-Thames) at $-11^{\circ} \mathrm{C}$. The diluent column was seeded 3-10 min later by touching the wall of the straw with a spatula precooled in liquid nitrogen $\left(-196^{\circ} \mathrm{C}\right)$. Five minutes later, the chamber was cooled at a rate of $5^{\circ} \mathrm{C} \mathrm{min}{ }^{-1}$, and when the temperature reached $-130^{\circ} \mathrm{C}$ the straws were immersed in liquid nitrogen. (ii) The straws were cooled rapidly (at approximately $200^{\circ} \mathrm{C} \mathrm{min}-1$ ). Straws were placed in cold nitrogen vapour $\left(<-170^{\circ} \mathrm{C}\right)$ for at least $3 \mathrm{~min}$ and then plunged into liquid nitrogen. (iii) The straws were cooled very rapidly (at approximately $2500^{\circ} \mathrm{C} \mathrm{min}^{-1}$ ). The column of solution VS3a and about $1 \mathrm{~cm}$ of the column of diluent were immersed in liquid nitrogen for about $20 \mathrm{~s}$. The straw was then placed into cold nitrogen vapour (as described above) for $3 \mathrm{~min}$ to allow the diluent column to crystallize slowly. Straws were stored submerged in liquid nitrogen for periods of between 1 day and 13 months.

Vitrified embryos were warmed using one of three methods. (i) They were warmed very rapidly (at approximately $2000^{\circ} \mathrm{C}$ $\min ^{-1}$, over the range -100 to $-30^{\circ} \mathrm{C}$ ). Straws were removed from liquid nitrogen, held horizontally in the air at $20^{\circ} \mathrm{C}$ for $10 \mathrm{~s}$ and then immersed in water at $20^{\circ} \mathrm{C}$ for $10 \mathrm{~s}$. The short period in air reduces the likelihood of fracture of the embryo suspension (Rall and Meyer, 1989). (ii) The embryos were warmed rapidly (at approximately $200^{\circ} \mathrm{C} \mathrm{min}{ }^{-1}$ ). Straws were held horizontally in the air for 1 min (to allow the embryo suspension to warm to about $-20^{\circ} \mathrm{C}$ ), and then immersed in water at $20^{\circ} \mathrm{C}$ for $6 \mathrm{~s}$ to melt the diluent. (iii) The embryos were warmed slowly (at approximately $20^{\circ} \mathrm{C} \mathrm{min}^{-1}$ ). Straws were transferred into a $17 \mathrm{~mm} \times 180 \mathrm{~mm}$ Pyrex tube previously cooled to approximately $-170^{\circ} \mathrm{C}$ in liquid nitrogen and allowed to warm in air. When the measured temperature of replicate straws containing a 40 gauge thermocouple warmed to about $-20^{\circ} \mathrm{C}$, straws were immersed in water at $20^{\circ} \mathrm{C}$ for $6 \mathrm{~s}$ to melt the diluent.

\section{Preparation of one-step straws for controlled slow freezing}

Columns of a diluent ( $1.0 \mathrm{~mol}$ sucrose $\mathrm{I}^{-1}$ in PBI) and cryoprotectant solution ( $1.5 \mathrm{~mol}$ glycerol $\mathrm{l}^{-1}$ in PBI) were placed into a $0.25 \mathrm{ml}$ plastic insemination straw using a modification of the procedure described by Rall (1992a). (i) The cotton-polyvinyl alcohol plug was pushed a total of $9 \mathrm{~mm}$ into the straw to facilitate heat-sealing. (ii) $\mathrm{A} 6.8 \mathrm{~cm}$ column of the diluent solution was aspirated into a straw, followed by an air bubble $0.8 \mathrm{~cm}$ long, a $0.8 \mathrm{~cm}$ column of cryoprotectant solution, a $0.8 \mathrm{~cm}$ air bubble, a $1 \mathrm{~cm}$ column of the cryoprotectant solution, and finally air until the first column contacted and wetted the cotton plug. (iii) The end of the straw closest to the cotton plug was heat-sealed and a handle $(0.5 \mathrm{ml}$ plastic insemination straw) was slip-fitted over the heat seal (Fig. 1).

\section{Controlled slow freezing and thawing of embryos}

Embryos were placed in a solution of $1.5 \mathrm{~mol}$ glycerol $1^{-1}$ in PB1 for $10 \mathrm{~min}$ at room temperature. Groups of embryos (10-20 per group) were then pipetted into the final column of $1.5 \mathrm{~mol}$ glycerol $\mathrm{l}^{-1}$ in straws prepared as described above, and the straws were heat-sealed. Twenty minutes after placing the embryos in the glycerol $\left(1.5 \mathrm{~mol} \mathrm{l}^{-1}\right)$ solution, straws were placed in an ethanol bath (Biocool; FTS Systems, Stone Ridge, $\mathrm{NY}$ ) precooled to $-7^{\circ} \mathrm{C}$. After $0.5 \mathrm{~min}$, straws were partially withdrawn from the ethanol and the sucrose column was seeded by touching the wall of the straw with a spatula 
precooled in liquid nitrogen. Straws were held at the seeding temperature for $10 \mathrm{~min}$ and then the bath was cooled at a rate of $0.5^{\circ} \mathrm{C} \min ^{-1}$ to $-40^{\circ} \mathrm{C}$. After $10 \mathrm{~min}$ at $-40^{\circ} \mathrm{C}$, straws were transferred into liquid nitrogen and stored submerged in liquid nitrogen for periods between 1 day and 13 months.

Slowly frozen embryos were thawed rapidly (at approximately $2000^{\circ} \mathrm{C} \min ^{-1}$ ) by removing the straw from liquid nitrogen, holding it horizontally in air at room temperature for $10 \mathrm{~s}$ and then immersing it in water at $20^{\circ} \mathrm{C}$ for $10 \mathrm{~s}$.

\section{One-step dilution of embryos}

Vitrified and frozen embryos were diluted from the cryoprotectant solution using a modification of the one-step method described by Leibo (1984). (i) After warming and removing the handle, the straw was held firmly at the plugged end and shaken vigorously to dislodge the air bubbles and mix the contents. (ii) The straw was incubated plug end up in water at $36^{\circ} \mathrm{C}$ for $3 \mathrm{~min}$ and then placed plug end down in water at $20^{\circ} \mathrm{C}$ for $1 \mathrm{~min}$. (iii) The straw was held at the end opposite to the plug and shaken until the air bubbles migrated to the opposite end. (iv) The straw was placed in water at $20^{\circ} \mathrm{C}$ for 2-5 min and the contents were then expelled into an empty Petri dish. (v) The shrunken embryos were collected and placed in Medium M2 for 10 min to allow the cytoplasm to rehydrate. Embryo survival was assayed in vitro or in vivo.

\section{Survival assays}

In vitro. Embryos recovered from a single straw were cultured together in a $10 \mu \mathrm{l}$ drop ( $<20$ embryos per drop) of a bicarbonate-buffered Krebs-Ringer medium (MI6: Whittingham, 1971) supplemented with $4 \mathrm{mg} \mathrm{BSA} \mathrm{ml}^{-1}$ (M16 plus BSA), in the well of a microwell culture plate (No. 452256; Nunc, Roskilde) under silicone oil at $38^{\circ} \mathrm{C}$ in an atmosphere of $7 \% \mathrm{CO}_{2}, 5 \% \mathrm{O}_{2}$ and $88 \% \mathrm{~N}_{2}$. Embryonic development was determined by examination using a microscope $(\times 100)$ at intervals of $24 \mathrm{~h}$ for $72 \mathrm{~h}$. Survival was defined as the percentage of recovered embryos developing to expanded blastocysts after $48 \mathrm{~h}$.

In vivo. Embryos were cultured overnight (18-24 h) in drops of M16 plus BSA under light liquid paraffin oil (BDH; Poole) in a plastic Petri dish (Falcon, Becton Dickinson; Lincoln Park, NJ) at $37^{\circ} \mathrm{C}$ in a humidified atmosphere of $5 \% \mathrm{CO}_{2}$ in air. Embryos that developed to the morula or early blastocyst stage were transferred surgically to the uterine horns (4-7 embryos per horn) of recipient females on day 3 of pseudopregnancy. Some recipients received frozen embryos in one horn and vitrified embryos in the contralateral horn (Expt 1). Vitrified embryos were assigned alternately to the right and left horns of consecutive recipients as a precaution against bias due to technical differences in the ease of transfer into uterine horns. Other recipients received vitrified or frozen embryos in both uterine horns (Expt 2).

Recipient females were adult $\mathrm{C} 57 \mathrm{BL} / 6 \mathrm{Lac} \times \mathrm{CBA} / \mathrm{CaLac} \mathrm{F}_{\mathrm{I}}$ hybrid mice mated with sterile males heterozygous for the translocation T145H (Lyon and Meredith, 1966) to induce pseudopregnancy. The day on which a copulation plug was found was designated day 1 of pseudopregnancy. Embryo recipients were allowed to produce litters or were autopsied on day 15 or 16 of gestation. When recipients produced litters, the number and sex of normal pups were recorded; when autopsy was performed on day 15 or 16 , the number of normal fetuses and resorbing implantations were recorded.

\section{Statistical analyses}

The statistical significance of differences in the survival of embryos following cryopreservation treatments was determined using two-way analysis of variance (ANOVA) by procedure GLM (SAS Institute, 1990) or chi-squared analysis with Yates' correction for continuity. Data from a pairedcomparison of cryopreservation treatments were analysed either by two-way ANOVA for paired comparisons or by $t$ test for paired comparisons (Sokal and Rohlf, 1981). In all cases, data were transformed using the angular method for proportions, $\theta=\arcsin V_{p}$, where $p$ is the proportion of embryos surviving a treatment.

\section{Results}

\section{Vitrification and crystallization of solution VS3a during cooling and warming}

Straws prepared for vitrification but without embryos were cooled at rates of $5,10,200$ or $2500^{\circ} \mathrm{C} \mathrm{min}^{-1}$ to $-196^{\circ} \mathrm{C}$. Vitrification was assessed by visually inspecting the contents of the straws at $-196^{\circ} \mathrm{C}$. Solutions cooled at rates between 10 and $2500^{\circ} \mathrm{C} \mathrm{min}{ }^{-1}$ were transparent in appearance and were assumed to be vitrified. However, slow cooling at $5^{\circ} \mathrm{C}$ min $^{-1}$ yielded a mottled, milky white suspension, which is indicative of substantial crystallization. Straws containing vitrified solution VS3a were warmed at approximately 20, 200 or $2000^{\circ} \mathrm{C} \mathrm{min}^{-1}$, and the occurrence of crystallization was identified by the transient whitening of the solution. Solutions warmed at 200 or $2000^{\circ} \mathrm{C} \mathrm{min}^{-1}$ remained transparent; that is, they exhibited no evidence of devitrification (crystallization). However, vitrified solution VS3a whitened visibly (crystallized) when warmed slowly at $20^{\circ} \mathrm{C}$ min $^{-1}$. Visual estimates of the extent of whitening suggested that less ice formed during slow warming than during slow cooling.

\section{Injury associated with prolonged equilibration in solution VS3a}

Embryos exposed to solution VS3a for 1 or $5 \mathrm{~min}$ before dilution from the cryoprotectant without cooling exhibited high rates of development in vitro to expanded blastocysts (94\%,n=146 and $90 \%, n=69$, respectively). Prolonged exposure of embryos to solution VS3a for 10, 20 or $30 \mathrm{~min}$ before dilution resulted in progressively lower rates of development $(69 \%, n=61,52 \%, n=59$ and $31 \%, n=68$, respectively).

\section{Development of vitrified embryos in vitro}

The effect of the rate of cooling to $-196^{\circ} \mathrm{C}$ and the rate of warming on the survival of embryos in solution VS3a is shown 
Table 1. Survival of 8-12-cell mouse embryos cooled and warmed in solution VS3a to $-196^{\circ} \mathrm{C}$ at various rates

\begin{tabular}{|c|c|c|c|}
\hline Cooling conditions & Slow $\left(20^{\circ} \mathrm{C} \min ^{-1}\right)$ & $\begin{array}{l}\text { Warming conditions } \\
\text { Rapid }\left(200^{\circ} \mathrm{C} \min ^{-1}\right)\end{array}$ & Very rapid $\left(2000^{\circ} \mathrm{C} \mathrm{min}^{-1}\right)$ \\
\hline Slow $\left(5^{\circ} \mathrm{C} \min ^{-1}\right)$ & $75.2 \pm 4.4(11)$ & $88.8 \pm 4.3(9)$ & $92.9 \pm 2.1(13)$ \\
\hline Rapid $\left(200^{\circ} \mathrm{C} \mathrm{min}^{-1}\right)$ & $80.9 \pm 4.7(12)$ & $86.1 \pm 3.7(14)$ & $90.9 \pm 2.5(24)$ \\
\hline Very rapid $\left(2500^{\circ} \mathrm{C} \mathrm{min}^{-1}\right)$ & $81.5 \pm 4.2(13)$ & $97.1 \pm 1.6(15)$ & $91.1 \pm 2.2(15)$ \\
\hline
\end{tabular}

Values are means \pm SEM survival of embryos (\%) developing to expanded blastocysts in culture. Number of replicate samples is given in parentheses.

Table 2. Estimate of overall survival in vivo following cryopreservation by vitrification in VS3a or controlled slow freezing of 8-12-cell mouse embryos

\begin{tabular}{|c|c|c|c|c|c|c|c|c|}
\hline Treatment & $\begin{array}{l}\text { Number } \\
\text { of embryos } \\
\text { thawed }\end{array}$ & $\begin{array}{c}\text { Number of } \\
\text { morulae and } \\
\text { blastocysts after } \\
\text { culture }(\%)\end{array}$ & $\begin{array}{l}\text { Number of } \\
\text { embryos } \\
\text { transferred } \\
\text { (number of } \\
\text { recipients) }\end{array}$ & $\begin{array}{l}\text { Number of } \\
\text { recipients } \\
\text { establishing } \\
\text { pregnancy }\end{array}$ & $\begin{array}{l}\text { Number of } \\
\text { implantations } \\
\text { on day } 15 \\
\text { of pregnancy }\end{array}$ & $\begin{array}{c}\text { Number of } \\
\text { normal fetuses } \\
\text { on day } 15 \\
\text { of pregnancy } \\
(\%)\end{array}$ & $\begin{array}{l}\text { Number of } \\
\text { normal pups } \\
(\%)\end{array}$ & $\begin{array}{l}\text { Estimated } \\
\text { overall \% }^{\text {survival }}{ }^{\text {d }}\end{array}$ \\
\hline \multirow[t]{2}{*}{ Vitrification } & 206 & $199(97 \%)$ & $\begin{array}{c}127(22)^{\mathrm{a}} \\
26(2)^{\mathrm{b}} \\
46(4)^{\mathrm{b}}\end{array}$ & $\begin{array}{r}22 \\
2 \\
3\end{array}$ & $\begin{array}{c}97(76 \%) \\
20(77 \%) \\
-\end{array}$ & $\begin{array}{c}93(73 \%) \\
17(65 \%) \\
-\end{array}$ & $\frac{-}{19(41 \%)}$ & \\
\hline & & Total: & $199(28)$ & 27 & 117 & 110 & 19 & $63 \%$ \\
\hline \multirow[t]{2}{*}{ Slow freezing } & 157 & $155(99 \%)$ & $\begin{array}{l}129(22)^{\mathrm{a}} \\
26(3)^{\mathrm{c}}\end{array}$ & $\begin{array}{r}22 \\
2\end{array}$ & $\begin{array}{c}110(85 \%) \\
-\end{array}$ & $\begin{array}{c}105(81 \%) \\
-\end{array}$ & 14 $\overline{(54 \%)}$ & \\
\hline & & Total: & $155(25)$ & 24 & 110 & 105 & 14 & $76 \%$ \\
\hline
\end{tabular}

${ }^{\text {a } V i t r i f i e d ~ e m b r y o s ~ w e r e ~ t r a n s f e r r e d ~ i n t o ~ o n e ~ u t e r i n e ~ h o r n ~ a n d ~ s l o w l y ~ f r o z e n ~ e m b r y o s ~ i n t o ~ t h e ~ c o n t r a l a t e r a l ~ h o r n ~(E x p t ~ 1) . ~}$

${ }^{b}$ Vitrified embryos were transferred into both uterine horns (Expt 2).

'Slowly frozen embryos were transferred into both uterine horns (Expt 2).

${ }^{d}$ Overall estimated survival based on the number of embryos thawed.

in Table 1. A high rate of development in vitro (86-97\%) was obtained when the embryo suspensions were cooled and warmed at rates of $200^{\circ} \mathrm{C} \mathrm{min}-1$ or higher; that is, in conditions that ensure vitrification and prevent devitrification. Similarly, high rates of survival $(75-93 \%)$ were obtained after slow cooling at $5^{\circ} \mathrm{C} \mathrm{min}^{-1}$ or slow warming at $20^{\circ} \mathrm{C} \mathrm{min}^{-1}$ or both treatments, even though the formation of ice was observed in those suspensions. Statistical analysis of these data indicated that there was no significant effect of the cooling rate or the interaction of cooling and warming rates on the survival of embryos (two-way ANOVA, $F_{s}=1.34, P>0.26$ ). However, the warming rate had a significant effect on survival $\left(F_{\mathrm{s}}=11.02 ; P<0.005\right)$. Multiple pairwise comparisons of all combinations of warming rates indicated that only slow warming at $20^{\circ} \mathrm{C} \min ^{-1}$ resulted in a small but statistically significant reduction in survival (Tukey's studentized range test, $P<0.05)$.

\section{Implantation and development of vitrified and slowly frozen embryos}

Embryos were either vitrified in solution VS3a using a cooling rate of $200^{\circ} \mathrm{C} \mathrm{min}^{-1}$ or frozen slowly in $1.5 \mathrm{~mol}$ glycerol $1^{-1}$ (Table 2). A total of 206 vitrified and 157 slowly frozen embryos were warmed rapidly $\left(2000^{\circ} \mathrm{C} \mathrm{min}{ }^{-1}\right)$, diluted from the cryoprotectant and cultured in vitro for $24 \mathrm{~h}$. Virtually all $(97 \%)$ of 363 cryopreserved embryos developed to morulae or blastocysts. A total of 199 vitrified and 155 frozen embryos were transferred to 31 pseudopregnant recipients, of which 29 females (94\%) established pregnancy. Overall, $63 \%$ of vitrified embryos and $76 \%$ of frozen embryos developed to form normal late-stage fetuses or liveborn offspring (Table 2).

Embryos were transferred into recipient females using one of two experimental designs. Expt 1 yielded a direct comparison of the relative abilities of vitrified and slowly frozen embryos to develop in vivo. A total of 22 recipient females received vitrified embryos in one uterine horn and slowly frozen embryos in the contralateral horn. A total of 127 vitrified and 129 slowly frozen embryos were transferred and all 22 recipients established pregnancy (Table 2). Analysis using the two-way ANOVA for paired comparisons (Table 3) indicated that the rates of development to normal fetuses of vitrified and slowly frozen embryos did not differ $(73$ versus $81 \%$, respectively; $F_{s}=2.51, P>0.12$ ). Furthermore, differences between embryo transfer recipients were not a significant source of variation in this experiment $\left(F_{\mathrm{s}}=0.85, P>0.5\right)$. Similarly, no 
Table 3. Two-way ANOVA table of paired comparison of the development of mouse embryos to normal fetuses in vivo following cryopreservation by vitrification or slow freezing

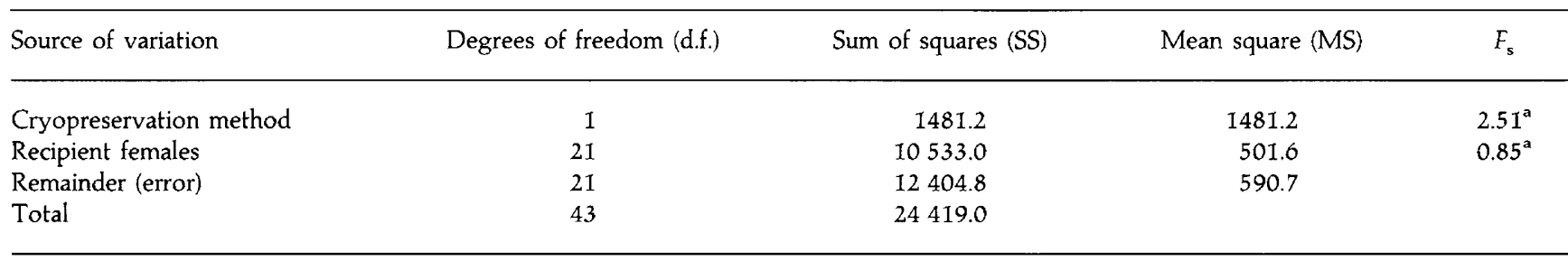

${ }^{a}$ Not significant.

Statistical table $F$ values: $F_{0.1|1,21|}=2.96 ; F_{0.05 \mid 1,21]}=4.32 ; F_{0.01[1,21]}=8.02$.

statistically significant differences were detected in the rates of implantation $\left(F_{s}=1.76, P>0.19\right)$ and post-implantation mortality $\left(F_{\mathrm{s}}=0.59, P>0.45\right)$.

In Expt 2, a total of 46 vitrified embryos were transferred to both uterine horns of four recipients, of which three established pregnancy and delivered 19 normal pups ( 13 females, 6 males) (Table 2). A total of 26 slowly frozen embryos were transferred into both uterine horns of three recipients, of which two established pregnancy and delivered 14 normal pups (6 females, 8 males) (Table 2). The proportion of embryos developing to liveborn offspring following either cryopreservation method was not different (Chi-squared analysis, $P>0.3$ ).

Finally, the remaining 26 vitrified embryos were transferred into two recipients. On day 15 of gestation, 17 normal fetuses and three resorbing implantations were observed (Table 2).

\section{Discussion}

High rates of development in vitro and in vivo were obtained when 8-12-cell mouse embryos were cryopreserved by a simple vitrification procedure that used a solution containing glycerol and BSA, step-wise equilibration at room temperature and dilution with sucrose within the straw. Cooling and warming conditions did not markedly affect the survival of embryos, even when ice formed in the suspension during slow cooling $\left(5^{\circ} \mathrm{C} \mathrm{min}{ }^{-1}\right)$ or slow warming $\left(20^{\circ} \mathrm{C} \mathrm{min}{ }^{-1}\right)$. However, the combination of slow cooling and slow warming resulted in a small (10-15\%) but statistically significant decrease in survival. These results confirm and expand previous reports that embryos frozen or vitrified in glycerol solutions tolerate crystallization of the suspension during warming (Rall and Polge, 1984; Rall, 1987). By contrast, none of the embryos vitrified in solutions based on dimethylsulfoxide or propylene glycol survive when ice forms in the suspension during slow warming (Rall and Fahy, 1985; Rall, 1987).

Solution VS3a is similar to that reported previously (VS3, Rall, 1987), with three exceptions. First, the $\mathrm{pH}$ of the solution was adjusted to 7.2. Second, BSA was substituted for the synthetic polymer polyethylene glycol. This eliminates the possibility of cell fusion associated with exposure to high concentrations of polyethylene glycol (Pontecorvo, 1975). BSA was selected because it is a common component of embryo handling and culture media, and the concentration of albumin added to solution VS3a, $6 \%(\mathrm{w} / \mathrm{v})$, is similar to the concentration of protein normally present in serum (Kaneko, 1989).
Third, solution VS3a was prepared using a modified PBS solution ( $\mathrm{PB} 1$; Whittingham, 1974) without reducing the concentrations of calcium, magnesium or phosphate ions. Unlike vitrification solutions containing polyethylene glycol and dimethylsulfoxide or propylene glycol, solution VS3a does not reduce the solubility of divalent cations. This property may be related, in part, to the mechanism proposed by Timasheff and colleagues (Gekko and Timasheff, 1981; Timasheff, 1993) to explain the ability of glycerol and chemically similar nonelectrolytes to protect proteins from denaturation.

Solution VS3a was prepared in a manner that maintained the concentration of saline components of PBI on a molar basis (moles salt litre ${ }^{-1}$ solution). This contrasts with the methods reportedly used to prepare other vitrification solutions, which maintain a constant concentration of salts on a molal basis (moles salt $\mathrm{kg}^{-1} \mathrm{H}_{2} \mathrm{O}$ ) but which reduce the concentration of saline components by about $50 \%$ on a molar basis (Scheffen et al., 1986; Kasai et al., 1990). Such a reduction may result in osmotic imbalances when cells are equilibrated in solutions of permeating cryoprotectants prepared by the molal method. On the basis of studies with human erythrocytes, Meryman and Douglas (1982) suggest that the molar definition is preferable when the cryoprotectant concentration is greater than $4 \mathrm{~mol} \mathrm{l}^{-1}$. Recently, Papis et al. (1993) compared both methods for maintaining the concentration of saline components in a rabbit embryo vitrification solution. They report that the molar approach yields higher embryo viability after vitrification than does the molal approach.

The total concentration of solutes in solution VS3a was adjusted to yield a stable vitreous state when cooled and warmed at moderate rates. Our observations indicate that this goal was achieved. No visible ice crystallization occurred when the solution was cooled at rates of $100^{\circ} \mathrm{C} \mathrm{min}^{-1}$ or more, or when vitrified samples were warmed at rates of $200^{\circ} \mathrm{C} \mathrm{min}^{-1}$ or more. However, either slow cooling at $5^{\circ} \mathrm{C} \min ^{-1}$ or slow warming at $20^{\circ} \mathrm{C} \mathrm{min}{ }^{-1}$ resulted in visible crystallization. The fact that more than $75 \%$ of embryos equilibrated in solution VS3a developed normally in vitro after cooling and warming at these low rates indicated that, under these conditions, crystallization of the embryo suspension was not inconsistent with high survival after thawing. The mechanism of survival is presumably similar to that proposed to explain the similarly high survival of embryos cryopreserved by the so-called ultrarapid freezing procedure (Szèll and Shelton, 1986; Trounson et al., 1987; Leibo, 1989; Mazur, 1990). According to this view, osmotic dehydration before cooling and warming 
increases the concentration of cytoplasmic solutes, which prevents the formation of lethal quantities of intracellular ice.

The formation of ice in a straw containing embryos suspended in solution VS3a does not necessarily indicate that ice has formed in the cytoplasm of embryos. Indeed, knowing the glass-forming tendency of a bulk vitrification solution provides little or no information regarding the likelihood of vitrification within a cell or embryo. Experimental evidence suggests that rapidly cooled embryos vitrify as defined by the lack of intracellular ice when examined using electron microscopy (Valdez et al., 1990). Rall (1987) proposed that cellular dehydration during the step-wise equilibration procedure described here may yield a concentrated cytoplasm that has greater glass-forming abilities than that of the suspending solution. According to this view, osmotic dehydration during exposure to $65 \%$ VS3a and solution VS3a of the equilibration procedure results in the exosmosis of cytoplasmic water and a concomitant increase in the concentration of endogenous macromolecules and glycerol that permeate into the cytoplasm during equilibration in $25 \%$ VS3a. Since the cytoplasm of preimplantation embryos is reported to contain approximately $15 \%(\mathrm{w} / \mathrm{v})$ protein in normal isotonic conditions (see Rall, 1987), osmotic dehydration produces approximately a doubling of the initial concentration of endogenous macromolecules. Such an increase ought to result in a more stable cytoplasmic glass than the extracellular glass (solution VS3a) that contains $6 \%(\mathrm{w} / \mathrm{v}) \mathrm{BSA}$ The high rates of survival of vitrified embryos in this study are consistent with this suggestion.

The paired-comparison experimental design provided a powerful method for comparing the efficacy of vitrification and conventional slow freezing procedures. We analysed our results using a two-way ANOVA (Sokal and Rohlf, 1981) because this approach allows two components of variance (cryopreservation method and recipient females) to be measured. The more traditional method for analysing such data, the $t$ test for paired comparisons, yields the same conclusion with respect to the cryopreservation method but does not allow the variance component among recipient females to be measured. Our analysis indicated that the developmental rates of vitrified and slowly frozen embryos to normal fetuses were statistically similar. Furthermore, there was no significant added variance among recipient females. This indicated that there were no significant differences (such as genetic, environmental or technical) in the ability of recipient females used in our experiment to establish pregnancies and gestate cryopreserved embryos.

Estimates of the overall efficiency of any embryo cryopreservation procedure is best expressed in terms of overall survival (i.e. the ratio of the number of normal pups or fetuses to the number of embryos thawed). Expt 1 provided a direct estimate of overall efficiency of vitrification in VS3a and slow freezing (Table 2). The overall estimates of the development of vitrified and slowly frozen embryos reported here compare favourably to other reports. For example, Wood et al. (1987) and Glenister et al. (1990) provided estimates of 16-66\% survival for slowly frozen mouse embryos from various inbred, hybrid and outbred genotypes. Overall survival rates following the vitrification of mouse embryos range from 18 to $62 \%$ (Scheffen et al., 1986; Rall et al., 1987; Kasai et al., 1990, 1992).
This study has defined a simple cryopreservation procedure for 8-12-cell mouse embryos that yields high overall rates of survival in vitro and in vivo. Other important features of our vitrification procedure include: (i) a nontoxic vitrification solution containing glycerol and BSA; (ii) step-wise equilibration at room temperature; (iii) the widest range of cooling and warming rates of any embryo cryopreservation procedure reported to date; and (iv) sucrose dilution of cryoprotectant within the straw container in which the embryos were cryopreserved.

The authors thank P. M. Schmidt and D. E. Wildt for comments on the manuscript and S. P. Leibo for stimulating discussions. This study was supported, in part, by Rio Vista International, Inc., Medical Research Council (UK), Friends of the National Zoo, and the National Institute on Aging, NIH (1 YOI AG10164). W. F. Rall is currently supported by a National Research Council Senior Research Associateship.

\section{References}

Fulton BP and Whittingham DG (1978) Activation of mammalian oocyte by intracellular injection of calcium Nature 273 149-151

Gekko K and Timasheff SN (1981) Mechanism of protein stabilization by glycerol: preferential hydration in glycerol-water mixtures Biochemistry 20 4667-4676

Glenister PH, Whittingham DG and Wood MJ (1990) Genome cryopreservation: a valuable contribution to mammalian genetic research Genetical Research $\mathbf{5 6}$ 253-258

Ishimori H, Takahashi Y, Kanagawa H (1992) Viability of vitrified mouse embryos using various cryoprotectant mixtures Theriogenology $37481-487$

Kaneko JJ (1989) Clinical Biochemistry of Domestic Animals (4th Edn) pp 888-890. Academic Press, New York

Kasai M, Komi JH, Takakamo A, Tsudera H, Sakurai T and Machida T (1990) A simple method for mouse embryo cryopreservation in a low toxicity vitrification solution without appreciable loss of viability Journal of Reproduction and Fertility $\mathbf{8 9} 91-97$

Kasai M, Nishimori N, Zhu SE, Sakurai T and Machida T (1992) Survival of mouse morulae vitrified in an ethylene glycol-based solution after exposure to the solution at various temperatures Biology of Reproduction 47 1134-1139

Leibo SP (1984) A one-step method for direct nonsurgical transfer of frozenthawed bovine embryos Theriogenology 21 767-790

Leibo SP (1986) Cryobiology: preservation of mammalian embryos Genetic Engineering of Animals, pp 251-272 Eds JW Evans and A Hollander. Plenum Publishing Corporation, New York

Leibo SP (1989) Equilibrium and nonequilibrium cryopreservation of embryos Theriogenology 31 85-93

Leibo SP and Mazur P (1978) Methods for the preservation of mammalian embryos by freezing Methods in Mammalian Reproduction. pp 179-201 Ed. JC Daniel, Jr. Academic Press, New York

Lyon MF and Meredith R (1966) Autosomal translocations causing male sterility and variable aneuploidy in the mouse Cytogenetics 5 335-354

Massip A, van der Zwalmen P and Leroy F (1984) Effect of stage of development on survival of mouse embryos frozen-thawed rapidly Cryobiology $\mathbf{2 1}$ 574-577

Massip A, van der Zwalmen P and Ectors F (1986) Pregnancies following transfer of cattle embryos preserved by vitrification Cryo-Letters 7 270-273

Mazur P (1990) Equilibrium, quasi-equilibrium and nonequilibrium freezing of mammalian embryos Cell Biophysics 17 53-92

Meryman HT and Douglas MSt.J (1982) Isotonicity in the presence of penetrating cryoprotectants Cryobiology $19565-569$

Papis K, Fujikawa S, Kojima T and Oguri N (1993) Effect of the composition of vitrification media on survival of rabbit embryos Cryobiology 30 98-105

Pontecorvo G (1975) Production of mammalian somatic cell hybrids by means of polyethylene glycol treatment Somatic Cell Genetics 1 397-400

Rall WF (1987) Factors affecting the survival of vitrified mouse embryos Cryobiology 24 387-402 
Rall WF (1992a) Cryopreservation of oocytes and embryos: methods and applications Animal Reproduction Science 28 237-245

Rall WF (1992b) Factors affecting the survival of mouse embryos vitrified in a solution containing glycerol and bovine serum albumin (VS3a) Cryobiology $29753-754$

Rall WF and Fahy GM (1985) Ice-free cryopreservation of mouse embryos at $-196^{\circ} \mathrm{C}$ by vitrification Nature $313573-575$

Rall WF and Meyer TK (1989) Zonae fracture damage to mammalian embryos during cryopreservation and its avoidance Theriogenology 31 683-692

Rall WF and Polge C (1984) Effect of warming rate on mouse embryos frozen and thawed in glycerol Joumal of Reproduction and Fertility 70 285-292

Rall WF, Wood MJ, Kirby C and Whittingham DG (1987) Development of mouse embryos cryopreserved by vitrification Joumal of Reproduction and Fertility 80 499-504

Renard JP and Babinet C (1984) High survival of mouse embryos after rapid freezing and thawing inside plastic insemination straws with 1,2 propanediol as cryoprotectant Journal of Experimental Zoology 230 443-448

SAS Institute Inc. (1990) The GLM procedure. SAS/STAT Users Guide, Version 6 (4th Edn, Vol. 2), pp 891-996. SAS Institute Inc., Cary, NC

Scheffen B, van der Zwalmen P and Massip A (1986) A simple and effective procedure for preservation of mouse embryos by vitrification Cryo-Letters 7 260-269

Shaw JM, Diotallevi L and Trounson A (1991) A simple rapid dimethyl sulphoxide freezing technique for the cryopreservation of one-cell to blastocyst stage preimplantation mouse embryos Reproduction Fertility and Development 3 621-626

Sokal RR and Rohlf FJ (1981) Biometry (2nd Edn), pp 354-359. WH Freeman, New York

Szèll A and Shelton JN (1986) Role of equilibration before rapid freezing of mouse embryos Journal of Reproduction and Fertility $\mathbf{7 8} 699-703$

Tachikawa S, Otoi T, Kondo S, Machida T and Kasai M (1993) Successful vitrification of bovine blastocysts, derived by in vitro maturation and fertilization Molecular Reproduction and Development 34 266-271

Tada N, Sato M, Amann E and Ogawa S (1993) A simple and rapid method for cryopreservation of mouse 2-cell embryos by vitrification: beneficial effect of sucrose and raffinose on their cryosurvival rate Theriogenology 40 333-344

Takeda T, Elsden RP and Seidel GE, Jr (1984) Cryopreservation of mouse embryos by direct plunging into liquid nitrogen Theriogenology 21266 (Abstract)
Timasheff SN (1993) The control of protein stability and association by weak interactions with water: how do solvents affect these processes? Annual Review of Biophysics and Biomolecular Structure 22 67-97

Trounson A, Peura A and Kirby C (1987) Ultrarapid freezing: a new lost-cost and effective method of cryopreservation Fertility and Sterility 48 843-850

Tsunoda $\mathrm{Y}$ and Sugie T (1977) Survival of rabbit eggs preserved in plastic straws in liquid nitrogen Joumal of Reproduction and Fertility 49 173-174

Valdez CA, Abas-Mazni O, Kanagawa $\mathbf{H}$ and Fujikawa S (1990) Confirmation by cryo-electron microscopy of the absence of crystallization using a vitrification solution Cryo-Letters 11 351-358

Whittingham DG (1971) Culture of mouse ova Journal of Reproduction and Fertility Supplement 14 7-21

Whittingham DG (1974) Embryo banks in the future of developmental genetics Genetics 78 395-405

Whittingham DG, Leibo SP and Mazur P (1972) Survival of mouse embryos frozen to $-196^{\circ}$ and $-269^{\circ} \mathrm{C}$ Science $178411-414$

Whittingham DG, Wood MJ, Farrant J, Lee H and Halsey JA (1979) Survival of frozen mouse embryos after rapid thawing from $-196^{\circ} \mathrm{C}$ journal of Reproduction and Fertility 56 11-21

Willadsen SM (1977) Factors affecting the survival of sheep embryos during deep-freezing and thawing. In The Freezing of Mammalian Embryos (Ciba Foundation Symposium 52), pp 175-189 Eds K Elliott and J Whelan. Elsevier Science Publishers, Amsterdam

Wilmut I (1972) The effect of cooling rate, warming rate, cryoprotective agent, and stage of development on survival of mouse embryos during freezing and thawing Life Sciences 11 1071-1079

Wood MJ and Farrant J (1980) Preservation of mouse embryos by two-step freezing Cryobiology 17 178-180

Wood MJ and Rall WF (1992) Post-implantation development of 8-cell mouse embryos after vitrification or slow freezing in glycerol solutions Cryobiology 29754 (Abstract)

Wood MJ, Whittingham DG and Rall WF (1987) The low temperature preservation of mouse oocytes and embryos. Mammalian Development, pp 255-280 Ed. M Monk. IRL Press, Oxford 